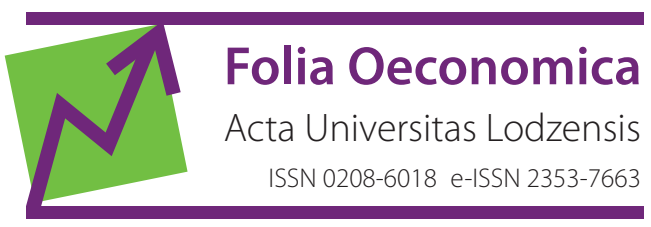

www.czasopisma.uni.lodz.pl/foe/

3(329) 2017

DOI: http://dx.doi.org/10.18778/0208-6018.329.10

\title{
Dorota Kałuża-Kopias
}

Uniwersytet Łódzki, Wydział Ekonomiczno-Socjologiczny, Zakład Demografii i Gerontologii

Społecznej, dkaluza@uni.lodz.pl

\section{Skłonność do migracji najstarszych seniorów - mieszkańców wielkich miast}

Streszczenie: Polska, jak większość krajów rozwiniętych, staje w obliczu starzenia się populacji. Dynamiczny wzrost liczby najstarszych mieszkańców naszego kraju (tzw. proces podwójnego starzenia się) i ich problemy w najbliższych dekadach zdominują prawdopodobnie dyskurs dotyczący seniorów. Celem niniejszego artykułu jest przedstawienie potencjalnych motywów migracji osób po 75. roku życia, mieszkańców wielkich miast w Polsce. Przedstawiony materiał pochodzi z badań własnych, które zostały zrealizowane między lutym a sierpniem 2016 roku. Wyniki analizy wskazują, że starsi Polacy niechętnie zmieniają miejsce zamieszkania, a głównym motywem migracji są problemy zdrowotne.

Słowa kluczowe: gerontologia, demografia, migracje seniorów, uwarunkowania migracji

JEL: J1 


\section{Wprowadzenie}

Starzenie się ludności najogólniej możemy zdefiniować jako wzrost w populacji odsetka osób po 60. lub 65. roku życia (przyjmując coraz częściej tę drugą wartość za granicę wieku). Proces ten jest konsekwencją utrzymywania się w długim okresie trendów w zakresie rozrodczości, umieralności (zwłaszcza w starszym wieku) oraz migracji (Kurek, 2008: 1-198; Szukalski, 2003: 3-81; 2010: 103-125). Wraz z zaawansowaniem procesu starzenia się ludności rozpoczął się niezmiernie ważny etap, zwany podwójnym starzeniem się, polegający na wzroście w populacji seniorów odsetka osób najstarszych. Jednocześnie gerontolodzy zwracają uwagę na heterogeniczność subpopulacji seniorów z punktu widzenia sprawności i zdrowia somatyczno-psychicznego oraz sytuacji społeczno-ekonomicznej (Mossakowska, Więcek, Błędowski, 2012: 11-397). Wśród seniorów zaczęto wyróżniać podgrupy: tzw. młodych starych (65-74 lata), starych starych (75-84 lata) oraz najstarszych starych (85 lat i więcej) (Suzman, Manton, Willis, 1992: 3-14; Longino, Bradley, 2001: 103-213).

Wzrost liczby najstarszych seniorów prowadzić może do wzrostu liczby migracji „wymuszonej” złym stanem zdrowia. Do takiego wniosku skłania przegląd literatury, zarówno polskiej, jak i zagranicznej. Prowadzone w Polsce w latach siedemdziesiątych i osiemdziesiątych XX wieku badania migracji osób starszych wyraźnie wskazują, iż występuje silna korelacja między stanem zdrowia a wymuszonym charakterem migracji (Latuch, 1977: 51-64; Stolarczyk, 1986: 106-123). W ostatnich dwóch dekadach w krajach anglojęzycznych przeprowadzono wiele analiz dotyczących przyczyn i wzorców migracji osób starszych, które pozwalają podzielić motywy migracji na wymuszone (złym stanem zdrowia, kosztami utrzymania) i dobrowolne (przejście na emeryturę, zmiana otoczenia na bardziej atrakcyjne) (m.in. Wiseman, 1980: 141-154; Longino, Bradley, 2001: 103-213; Walters, 2006: 38-66; Uren, Goldring, 2007: 31-41; La Parra, Mateo, 2008: 85-102). Nowym obszarem badań migracji osób starszych, który pojawił się w latach dziewięćdziesiątych, są przemieszczenia związane z opieką instytucjonalną, czyli „migracje” do domów opieki (,,migration” to nursing homes), które są związane z potrzebą długoterminowej opieki (za: Quandango, 2002: 120-135). Ponieważ - jak wskazują prognozy demograficzne - w nadchodzących dekadach wzrastać będzie wśród osób starszych odsetek najstarszych seniorów, można spodziewać się, jak wspomniano wcześniej, wzrostu liczby przeprowadzek, ,wymuszonych” złym stanem zdrowia i potrzebą opieki. Jednocześnie utrzymywanie się małodzietności prowadzić będzie do wzrostu obciążeń dla opiekunów rodzinnych w przypadku konieczności opieki nad starszym krewnym, najczęściej rodzicem, gdyż opieka nad seniorem będzie skupiona na jednej lub dwóch osobach. Ponadto wzrost emigracji po 2004 roku, głównie ludzi młodych, bezpośrednio przełoży się na relacje rodzinne i ograniczenie liczby osób mogących udzielić bezpośredniego wsparcia seniorom w czynnościach dnia codziennego. 
Celem niniejszego artykułu jest określenie skłonności do migracji w przyszłości i ustalenie potencjalnych motywów przyszłej przeprowadzki seniorów po 75. roku życia, mieszkających w wielkich miastach ${ }^{1}$. Pomysł badania narodził się w trakcie realizacji grantu NCN (B1411200000556000) pt. Opieka nad seniorami z perspektywy dwóch pokoleń - udzielajacych wsparcia $i$ wspieranych. Implikacje dla systemu opieki nad osobami starszymi, w którym problematyka migracji seniorów potraktowana została marginalnie, jako jeden z wielu równoległych wątków. Wstępne wyniki tego badania posłużyły do rozpoznania problemu i stanowiły cenne źródło informacji do omawianej w tym artykule części badania.

Niniejsze badanie przeprowadzone zostało w miesiącach luty-sierpień 2016 roku w pięciu największych miastach w Polsce. Postawione w nim zostały m.in. następujące hipotezy:

H1: Seniorzy to subpopulacja niechętnie zmieniająca miejsce zamieszkania.

H2: Wraz z wiekiem wzrasta prawdopodobieństwo wystąpienia migracji ,wymuszonej" złym stanem zdrowia i potrzebą opieki.

W każdym z miast zostało przebadanych 100 seniorów, którzy mieli ukończone 75 lat. Ze względu na specyfikę badanej grupy (stan zdrowia, poziom ufności) nie była to próba reprezentatywna. Doboru seniorów do badania starano się dokonać w ten sposób, aby struktura wieku badanych osób po 75. roku życia była zbliżona do struktury osób starszych w poszczególnych wielkich miastach. W dotarciu do seniorów pomogli lekarze pierwszego kontaktu pracujący w analizowanych miastach ${ }^{2}$.

W niniejszym artykule skupiono się na populacji osób w wieku 75 lat i więcej, zakładając, że grupa ta charakteryzuje się specyficznymi potrzebami zdrowotnymi, socjalnymi i opiekuńczymi (Szukalski, 2003: 10-81; Mossakowska, Więcek, Błędowski, 2012: 7-412). Prowadzone badania polskich seniorów (Synak, 2002: 7-210, Bień, 2002: 35-77, Mossakowska, Więcek, Błędowski, 2009: 7-410) jednoznacznie wskazują, iż - przechodząc do coraz starszych grup wiekowych - mamy do czynienia z pogarszaniem się stanu zdrowia, co prowadzi do wzrostu zapotrzebowania na wsparcie seniorów w czynnościach dnia codziennego, zarówno ze strony instytucji, jak i rodziny. W warunkach polskich rodzina odgrywa kluczową rolę w zapewnieniu potrzeb opiekuńczych starszym członkom rodziny (Szukalski, 2003: 15-22). Wydłużanie się trwania życia ludzkiego, czego naturalną konsekwencją jest dożywanie do sędziwego wieku, powoduje zwiększenie obciążeń zobowiązaniami opiekuńczymi osób w niemobilnym wieku produkcyjnym oraz „młodych starych”.

${ }^{1}$ Wyjaśnienia wymaga zastosowany w artykule termin „wielkie miasto”. W pracy tej sformułowanie to odnosić się będzie do pięciu największych miast polskich. W kolejności odpowiadającej wielkości zaludnienia są to: Warszawa, Kraków, Łódź, Wrocław i Poznań.

2 Chciałabym podziękować lekarzom z naukowych ośrodków medycznych z tych miast za pomoc w realizacji badania, a szczególnie dr. Dariuszowi Timlerowi z Uniwersytetu Medycznego w Łodzi, który ułatwił kontakty z pozostałymi ośrodkami. 
Wybór największych pod względem liczby ludności pięciu miast jako zbiorowości, w której badane będą migracje seniorów, nie jest przypadkowy. Dane z ostatniego NSP'2011, jak również najnowsza prognoza GUS z 2014 roku wskazują, iż wielkie miasta obecnie wyróżniają się i w nadchodzących dwóch dekadach wyróżniać się będą największym stopniem zaawansowania procesu starzenia się ludności.

W Polsce ostatnie badania monograficzne poświęcone w całości temu zagadnieniu realizowane były w latach siedemdziesiątych i osiemdziesiątych (Latuch, 1977: 51-69; Stolarczyk, 1985: 1-210; 1986: 106-123). W ostatnim okresie na istotny aspekt społeczny przemieszczeń osób starszych zwrócili uwagę, m.in.: D. Kałuża-Kopias (2008: 71-89; 2011: 69-107; 2014a: 91-120), Ł. Krzyżanowski (2012: 125-142) i E. Ptak (2012: 21-26).

\section{Starzenie się mieszkańców największych miast w Polsce}

Prezentowanym badaniem zostali objęci seniorzy będący mieszkańcami pięciu największych miast w Polsce (Warszawy, Krakowa, Łodzi, Wrocławia i Poznania). Ogółem w tych miastach zamieszkuje 11\% ludności Polski. Istotne znaczenie dla udziału seniorów w tych miastach miał ruch wędrówkowy ludności. Okres po II wojnie światowej przyniósł wzmożone ruchy migracyjne związane z wysiedlaniem ludności, napływem repatriantów i przemieszczeniami ludności wewnątrz kraju. Koleje lata przyniosły koncentrację inwestycji przemysłowych w dużych ośrodkach miejskich, które pociągały za sobą intensywny napływ ludności z obszarów wiejskich i mniejszych ośrodków miejskich, co przełożyło się w ostatnich latach na większe tempo wzrostu udziału seniorów w populacji. Ponadto, jak wskazuje P. Szukalski (2010: 103-125), wielkie miasta cechują się niższym poziomem umieralności wśród najstarszych seniorów niż dla Polski ogółem, co wpływa również na poziom zaawansowania procesu starzenia się ludności. Obecnie miasta te charakteryzują się największym zaawansowaniem procesu starzenia się ludności (tab. 1), co jest naturalną konsekwencją kształtowania się - w trakcie całego okresu powojennego - procesów demograficznych (intensywnego napływu ludności, niskiego poziomu dzietności i niskiej umieralności wśród seniorów). We wszystkich wielkich miastach udział osób mających 75 lat i więcej jest wyższy niż ogółem dla Polski, a udział seniorów mających 80 lat i więcej wśród osób, które ukończyły 75 lat, jest znacznie większy niż w mniejszych miastach i na obszarach wiejskich.

Jak wskazuje badanie PolSenior (Mossakowska, Więcek, Błędowski, 2012), starsi mieszkańcy wielkich miast są lepiej wykształceni w porównaniu do zbioro- 
wości mieszkańców Polski ogółem, co z kolei przekłada się na ich pozycję społeczną. Dziedziczenie statusu społecznego sprawia, że lepiej wykształceni seniorzy posiadają lepiej wykształcone dzieci, które z kolei są bardziej wygodnie i rzadkiej poświęcają swój czas starszym rodzicom, częściej wykorzystując wsparcie instytucjonalne w opiece nad seniorem (Szukalski, 2003: 36-45). Ponadto przemiany w rozrodczości doprowadziły do wykształcenia się rodziny nuklearnej, charakterystycznej dla miast. Jednopokoleniowość jest wyraźnie cechą największych miast w Polsce. Rodziny wielopokoleniowe stanowią niewielki udział w wielkomiejskim środowisku, w przeciwieństwie do obszarów wiejskich. Przemiany te nie pozostają bez wpływu na odsetek seniorów samotnie żyjących w wielkich miastach, który jest większy niż w mniejszych jednostkach administracyjnych (Szukalski, 2010: 407-419). Sytuacja ta nie pozostaje bez wpływu na poczucie zaniedbania i osamotnienia. Przywoływane wcześniej badanie PolSenior wskazuje, iż w przypadku wielkich miast odczucie zaniedbania jest większe niż w przypadku mieszkańców mniejszych miast i wsi.

Tabela 1. Struktura wieku ludności Polski i największych miast - stan na 30.06.2015 r.

\begin{tabular}{|l|r|r|r|r|r|r|r|}
\hline \multirow{2}{*}{ Wyszczególnienie } & Polska & Lódź & Wroclaw & Warszawa & Kraków & Poznań \\
\cline { 2 - 7 } w \% \\
\hline $\begin{array}{l}\text { \% osób w wieku 75 lat } \\
\text { i więcej w ogóle } \\
\text { ludności }\end{array}$ & 6,9 & 9,0 & 8,6 & 9,3 & 8,2 & 8,1 \\
\hline Grupa wiekowa & & & \multicolumn{7}{|c|}{ w \% } & \\
\hline $75-79$ & 45,9 & 38,5 & 39,2 & 38,7 & 40,9 & 40,8 \\
\hline 80 lat i więcej & 54,1 & 61,5 & 60,8 & 61,3 & 59,1 & 59,2 \\
\hline 75 i więcej & 100,0 & 100,0 & 100,0 & 100,0 & 100,0 & 100,0 \\
\hline
\end{tabular}

Źródło: baza danych Demografia GUS

Ostatnia prognoza GUS z 2014 roku wskazuje, iż w kolejnych dekadach seniorzy będą stanowić znaczącą grupę mieszkańców kraju, co generować będzie wzrost zapotrzebowania na różnorodne usługi społeczne dla tej właśnie grupy ludności. Ponadto widoczny od kilkunastu lat odpływ ludności z wielkich miast na ich obrzeża - suburbanizacja - oznacza odpływ potencjalnych opiekunów osób starszych, mogący pociągnąć za sobą z jednej strony migracje osób starszych, a z drugiej wzrost zapotrzebowania na opiekę instytucjonalną. 


\section{Migracje seniorów w największych polskich miastach}

Seniorzy po 75. roku życia stanowią wśród osób przybywających do wielkich miast niewielki odsetek - od 1,3\% w Warszawie do 2,1\% w Łodzi. Inaczej kształtuje się udział subpopulacji najstarszych seniorów w ogólnych rozmiarach odpływu. W przypadku ludności opuszczającej wielkie miasta w wyniku migracji udział ten waha się od 2,1\% w Poznaniu do 3,2\% w Warszawie (rys. 1).

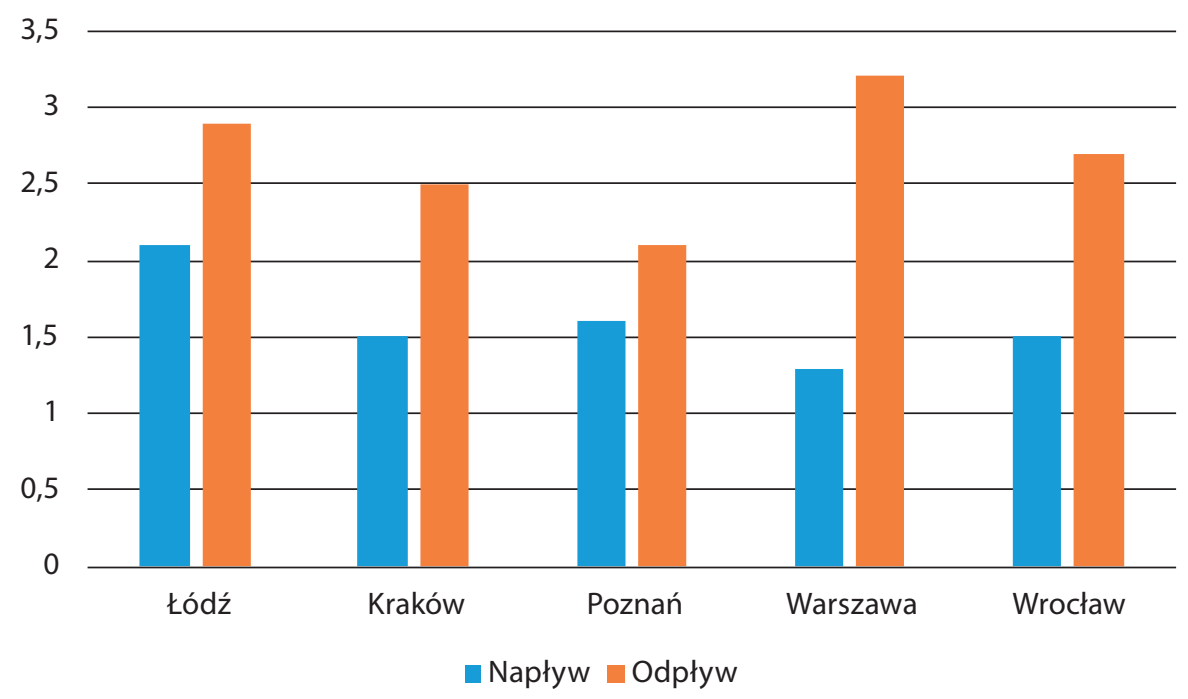

Rysunek 1. Odsetek osób po 75. roku życia w napływie i odpływie do/z wielkich miast w 2014 r. (w \%)

Źródło: opracowanie własne na podstawie bazy danych Demografia GUS

W pierwszej dekadzie obecnego stulecia przewaga odpływu seniorów nad ich napływem charakteryzowała wszystkie wielkie miasta (tab. 2). Przyglądając się rozmiarom natężenia migracji w poszczególnych grupach wiekowych osób starszych, widać, że wśród migrujących - zarówno w przypadku napływu, jak i opływu migracyjnego - najwięcej było najstarszych seniorów (po 85. roku życia).

Między 2000 a 2014 rokiem zauważyć można wyraźne zmniejszenie się intensywności odpływu seniorów z wielkich miast. Największy spadek częstości przemieszczeń widoczny był wśród osób po 85. roku życia.

Wszystkie wielkie miasta charakteryzowały się ubytkami migracyjnymi osób po 75. roku życia. Odnosząc wartości salda migracji do wielkości subpopulacji osób starszych w poszczególnych miastach, okazuje się, że w latach 2000-2014 największą intensywnością ubytku migracyjnego seniorów charakteryzował się 
Poznań. Na drugim biegunie znalazł się Kraków, który w całym badanym okresie miał najmniejsze rozmiary natężenia sald migracji (tab. 3). Mimo że w wielkich miastach występował ubytek migracyjny subpopulacji seniorów, to Kraków i Wrocław charakteryzowały się dodatnimi efektami (saldami) ruchu wędrówkowego w niektórych latach wśród najstarszych seniorów. Ubytki migracyjne osób starszych z wielkich miast mogą być konsekwencją suburbanizacji. Wraz z przenoszeniem się młodszych generacji na obszary podmiejskie przenoszą się również seniorzy, którzy podążają za swoimi opiekunami (najczęściej dziećmi), często będąc zależnymi od ich pomocy.

Tabela 2. Natężenie napływu i odpływu seniorów według wieku w wielkich miastach w wybranych latach (na 1000 osób)

\begin{tabular}{|c|c|c|c|c|c|c|c|c|}
\hline \multirow{4}{*}{$\begin{array}{c}\text { Grupy } \\
\text { wiekowe }\end{array}$} & \multicolumn{8}{|c|}{ Miasta } \\
\hline & \multicolumn{8}{|c|}{ Lata } \\
\hline & 2000 & 2005 & 2010 & 2014 & 2000 & 2005 & 2010 & 2014 \\
\hline & \multicolumn{4}{|c|}{ Naplyw } & \multicolumn{4}{|c|}{ Odpływ } \\
\hline \multicolumn{9}{|c|}{ Warszawa } \\
\hline $75-79$ & 1,56 & 1,82 & 1,37 & 1,72 & 2,37 & 2,68 & 2,50 & 0,23 \\
\hline $80-84$ & 1,51 & 2,26 & 1,72 & 1,77 & 2,09 & 2,52 & 2,54 & 0,26 \\
\hline $85+$ & 3,57 & 3,86 & 2,64 & 2,60 & 4,99 & 3,23 & 3,69 & 0,45 \\
\hline \multicolumn{9}{|c|}{ Wrocław } \\
\hline $75-79$ & 1,93 & 2,53 & 1,50 & 1,47 & 3,21 & 2,87 & 3,68 & 0,26 \\
\hline $80-84$ & 2,58 & 3,63 & 2,11 & 1,96 & 1,98 & 3,70 & 4,03 & 0,29 \\
\hline $85+$ & 6,98 & 3,78 & 4,07 & 5,46 & 6,83 & 3,34 & 4,51 & 0,50 \\
\hline \multicolumn{9}{|c|}{ Łódź } \\
\hline $75-79$ & 1,72 & 1,82 & 1,39 & 0,17 & 2,43 & 2,66 & 2,11 & 0,04 \\
\hline $80-84$ & 1,19 & 1,04 & 0,67 & 0,75 & 1,45 & 2,45 & 1,60 & 0,12 \\
\hline $85+$ & 3,03 & 1,96 & 1,66 & 1,00 & 3,72 & 4,01 & 3,13 & 0,19 \\
\hline \multicolumn{9}{|c|}{ Kraków } \\
\hline $75-79$ & 2,41 & 2,02 & 1,67 & 1,21 & 2,83 & 2,48 & 2,45 & 0,22 \\
\hline $80-84$ & 2,39 & 3,23 & 0,15 & 2,27 & 2,19 & 3,16 & 1,14 & 0,32 \\
\hline $85+$ & 4,34 & 3,77 & 3,31 & 4,23 & 5,14 & 3,43 & 3,54 & 0,38 \\
\hline \multicolumn{9}{|c|}{ Poznań } \\
\hline $75-79$ & 2,60 & 2,43 & 1,60 & 1,77 & 3,43 & 5,36 & 2,48 & 0,24 \\
\hline $80-84$ & 2,25 & 2,33 & 2,42 & 2,02 & 4,41 & 5,83 & 2,58 & 0,41 \\
\hline $85+$ & 5,93 & 4,62 & 4,05 & 4,20 & 9,83 & 4,91 & 3,74 & 0,67 \\
\hline
\end{tabular}

Źródło: opracowanie własne na podstawie bazy danych Demografia GUS oraz Rocznika Demograficznego GUS 2001 
Tabela 3. Salda migracji seniorów w wielkich miastach w wybranych latach (na 1000 osób)

\begin{tabular}{|c|c|c|c|c|c|c|c|c|c|c|c|c|c|c|c|c|c|c|c|c|}
\hline \multirow{3}{*}{ Grupa wiekowa } & \multicolumn{4}{|c|}{ Warszawa } & \multicolumn{4}{|c|}{ Wroclaw } & \multicolumn{4}{|c|}{ Lódź } & \multicolumn{4}{|c|}{ Kraków } & \multicolumn{4}{|c|}{ Poznań } \\
\hline & \multicolumn{20}{|c|}{ Lata } \\
\hline & ஓ̊ & ষ্ণ & 응 & 㐫 & 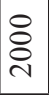 & ষ্ণ & $\stackrel{\circ}{\stackrel{\sim}{\circ}}$ & 穴 & ஓ & 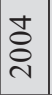 & 웅 & স্ণ & ঃ & ষ্ণ & $\stackrel{\circ}{\stackrel{2}{\sim}}$ & $\stackrel{\vec{\partial}}{\stackrel{\sim}{\sim}}$ & 요 & ষ্ণ & 웅 & $\stackrel{\nabla}{\stackrel{\sim}{d}}$ \\
\hline $75-79$ & $\begin{array}{l}\vec{\infty} \\
0 \\
1\end{array}$ & $\stackrel{\sim}{\sim}$ & $\stackrel{m}{\rightarrow}$ & $\begin{array}{l}n \\
\tilde{n} \\
i \\
1\end{array}$ & 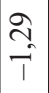 & $\mid \begin{array}{l}0 \\
\infty \\
0 \\
1\end{array}$ & $\frac{\infty}{i}$ & $\underset{7}{\rightarrow}$ & $\overrightarrow{\tilde{0}}$ & $\begin{array}{c}\infty \\
\infty \\
i\end{array}$ & $\overrightarrow{\hat{0}}$ & $\begin{array}{l}\overrightarrow{\tilde{N}} \\
\hat{i}\end{array}$ & 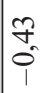 & $\frac{R}{i}$ & $\begin{array}{l}\infty \\
\hat{0} \\
i\end{array}$ & $\begin{array}{l}\infty \\
2 \\
\hat{i}\end{array}$ & $\begin{array}{l}\infty \\
\infty \\
0 \\
0\end{array}$ & $\underset{\substack{\uparrow \\
\uparrow}}{\infty}$ & $\stackrel{\infty}{\infty}$ & $\begin{array}{l}\forall \\
0 \\
0 \\
0\end{array}$ \\
\hline $80-84$ & $\begin{array}{l}2 \\
\text { ñ } \\
0\end{array}$ & ले & $\begin{array}{l}\infty \\
\infty \\
0 \\
1\end{array}$ & $\begin{array}{l}\infty \\
\dot{\infty} \\
\hat{\rho}\end{array}$ & $\begin{array}{l}0 \\
\tilde{n} \\
0\end{array}$ & $\begin{array}{l}n \\
\tilde{n} \\
0\end{array}$ & $\underset{\sim}{\overparen{T}}$ & 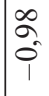 & 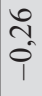 & $\begin{array}{l}n \\
\infty \\
0 \\
1\end{array}$ & $\hat{\sigma}$ & $\begin{array}{l}0 \\
n \\
0 \\
1\end{array}$ & $\frac{a}{0}$ & $\hat{\hat{\theta}}$ & $\begin{array}{l}\infty \\
\underset{T}{-} \\
-1\end{array}$ & $\begin{array}{l}0 \\
0 \\
0 \\
1\end{array}$ & $\frac{\bar{i}}{i}$ & $\begin{array}{l}\infty \\
\infty \\
0 \\
1\end{array}$ & $\stackrel{\Xi}{7}$ & $\frac{0}{i}$ \\
\hline 85 lat i więcej & 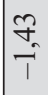 & $\begin{array}{l}\infty \\
0 \\
0 \\
0\end{array}$ & 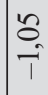 & 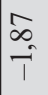 & $\frac{n}{0}$ & $\begin{array}{l}\mathcal{J} \\
\sim \\
i\end{array}$ & 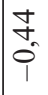 & $\stackrel{n}{\mathscr{n}}$ & $\begin{array}{l}0 \\
0 \\
0\end{array}$ & 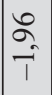 & $\underset{i}{\stackrel{f}{f}}$ & $\begin{array}{l}\tilde{\alpha} \\
\hat{O}\end{array}$ & $\begin{array}{l}\infty \\
0 \\
1\end{array}$ & $=$ & $\begin{array}{l}\tilde{2} \\
\hat{i} \\
i\end{array}$ & $\begin{array}{c}\infty \\
\infty \\
0 \\
0\end{array}$ & $\begin{array}{l}\text { वू } \\
\text { iे }\end{array}$ & $\begin{array}{l}\overrightarrow{\tilde{r}} \\
\stackrel{i}{i}\end{array}$ & $\begin{array}{l}\stackrel{一}{~} \\
\text { iे }\end{array}$ & $\begin{array}{l}\tilde{\sigma} \\
\stackrel{\gamma}{i}\end{array}$ \\
\hline
\end{tabular}

Źródło: opracowanie własne na podstawie bazy danych Demografia GUS oraz Rocznika Demograficznego GUS 2001

\section{Charakterystyka badanych seniorów}

Badana grupa 500 seniorów po 75 . roku życia charakteryzowała się przewagą kobiet - stanowiły $64 \%$ ogółu badanych. Poziom feminizacji wzrasta wraz z przechodzeniem do starszych roczników. Kobiety stanowiły $79 \%$ wśród seniorów po 85 . roku życia. Wśród respondentów największy udział we wszystkich miastach stanowiły osoby między 75. a 79. rokiem życia (średnio w pięciu miastach 39\%). Udział tej subpopulacji wynosił od 37\% w Warszawie do 42\% w Krakowie (tab. 4).

Tabela 4. Struktura wieku badanych seniorów w pięciu miastach (w \%)

\begin{tabular}{|l|c|c|c|c|c|c|}
\hline $\begin{array}{c}\text { Grupa } \\
\text { wiekowa }\end{array}$ & Lódź & Wroclaw & Warszawa & Kraków & Poznań & Ogólem \\
\hline $75-79$ & 38 & 39 & 37 & 42 & 40 & 39,2 \\
\hline $80-84$ & 32 & 33 & 34 & 31 & 32 & 32,4 \\
\hline $85+$ & 30 & 28 & 29 & 27 & 28 & 28,4 \\
\hline 75 i więcej & 100 & 100 & 100 & 100 & 100 & 100 \\
\hline
\end{tabular}

Źródło: wyniki badań własnych

W przypadku kobiet mamy do czynienia z porównywalnymi liczebnie wielkościami poszczególnych grup wiekowych, podczas gdy w populacji mężczyzn wyraźnie dominuje najmłodsza grupa, a pozostałe dwie z wyodrębnionych grup wiekowych są stosunkowo mało liczne. Prawidłowość ta występowała we wszystkich analizowanych miastach (tab. 5). 
Tabela 5. Struktura badanych ze względu na wiek i płeć (w \%)

\begin{tabular}{|l|l|c|c|c|c|}
\hline \multirow{3}{*}{ Miasto } & \multirow{2}{*}{ Płeć } & \multicolumn{3}{|c|}{ Grupa wiekowa } & \\
\cline { 3 - 6 } & & $\mathbf{7 5 - 7 9}$ & $\mathbf{8 0 - 8 4}$ & $\mathbf{7 5}$ i więcej & $\mathbf{8 5}$ i więcej \\
\hline \multirow{3}{*}{ Łódź } & Mężczyźni & 47,4 & 31,3 & 36 & 26,7 \\
\cline { 2 - 6 } & Kobiety & 52,6 & 68,8 & 64 & 73,3 \\
\cline { 2 - 6 } & Ogółem & 100 & 100 & 100 & 100 \\
\hline \multirow{4}{*}{ Wrocław } & Mężczyźni & 51,3 & 30,3 & 38 & 28,6 \\
\cline { 2 - 6 } & Kobiety & 48,7 & 69,7 & 62 & 71,4 \\
\cline { 2 - 6 } & Ogółem & 100 & 100 & 100 & 100 \\
\hline \multirow{4}{*}{ Karszawa } & Mężczyźni & 54,1 & 23,5 & 36 & 27,6 \\
\cline { 2 - 6 } & Kobiety & 45,9 & 76,5 & 64 & 72,4 \\
\cline { 2 - 6 } & Ogółem & 100 & 100 & 100 & 100 \\
\hline \multirow{3}{*}{ Poznám } & Mężczyźni & 47,6 & 32,3 & 36 & 22,2 \\
\cline { 2 - 6 } & Kobiety & 52,4 & 67,7 & 64 & 77,8 \\
\cline { 2 - 6 } & Ogółem & 100 & 100 & 100 & 100 \\
\hline & Mężczyźni & 50 & 34,4 & 36 & 17,9 \\
\cline { 2 - 6 } & Kobiety & 50 & 65,6 & 64 & 82,1 \\
\cline { 2 - 6 } & Ogółem & 100 & 100 & 100 & 100 \\
\hline
\end{tabular}

Źródło: wyniki badań własnych

Wśród badanych seniorów, którzy ukończyli 75. rok życia, przeważająca grupa (57,2\%) to wdowy i wdowcy (tab. 6). W związkach małżeńskich żyło 37,4\% respondentów. Osoby, które nigdy nie zawarły związku małżeńskiego lub których małżeństwo zakończyło się rozwodem, stanowiły niespełna $6 \%$ wszystkich badanych. Skala wdowieństwa była znacznie większa wśród starszych kobiet (70,8\%) niż mężczyzn (33,5\%).

Tabela 6. Struktura seniorów po 75. roku życia ze względu na płeć i stan cywilny, łącznie dla pięciu ankietowanych miast ( $\mathrm{w} \%)$

\begin{tabular}{|l|c|c|c|c|c|}
\hline \multicolumn{1}{|c|}{ Pleć } & $\begin{array}{c}\text { Panna/ } \\
\text { Kawaler }\end{array}$ & $\begin{array}{c}\text { Zamężna/ } \\
\text { Żonaty }\end{array}$ & $\begin{array}{c}\text { Wdowa/ } \\
\text { Wdowiec }\end{array}$ & $\begin{array}{c}\text { Rozwiedziona/ } \\
\text { Rozwiedziony }\end{array}$ & Ogólem \\
\hline Kobiety & 3,8 & 23,6 & 70,8 & 1,9 & 100,0 \\
\hline Mężczyźni & 2,7 & 61,5 & 33,5 & 2,2 & 100,0 \\
\hline Ogółem & 3,4 & 37,4 & 57,2 & 2,0 & 100,0 \\
\hline
\end{tabular}

Źródło: wyniki badań własnych

Mężczyźni zdecydowanie częściej niż kobiety pozostawali w związkach małżeńskich (64,5\%). Na taki stan rzeczy składa się zarówno nadumieralność mężczyzn, jak i tradycyjna różnica wieku między małżonkami (mąż starszy od żony od 2 do 5 lat). W przypadku pań w każdej z wydzielonych grup wiekowych przeważają zdecydowanie wdowy, a w przypadku mężczyzn niewielka przewaga wdowców nad mężczyznami będącymi w związkach małżeńskich występuje w najstarszej grupie wiekowej. 
Tabela 7. Struktura ze względu na wiek i stan cywilny łącznie dla pięciu ankietowanych miast (w \%)

\begin{tabular}{|l|c|c|c|c|c|}
\hline $\begin{array}{c}\text { Grupa } \\
\text { wiekowa }\end{array}$ & $\begin{array}{c}\text { Panna/ } \\
\text { Kawaler }\end{array}$ & $\begin{array}{c}\text { Zamężna/ } \\
\text { Żonaty }\end{array}$ & $\begin{array}{c}\text { Wdowa/ } \\
\text { Wdowiec }\end{array}$ & $\begin{array}{c}\text { Rozwiedziona/ } \\
\text { Rozwiedziony }\end{array}$ & Ogółem \\
\hline \multicolumn{7}{|c|}{ Kobiety } \\
\hline $75-79$ & 5,1 & 31,6 & 57,1 & 6,1 & 100,0 \\
\hline $80-84$ & 1,8 & 23,0 & 75,2 & 0,0 & 100,0 \\
\hline $85+$ & 4,7 & 16,8 & 78,5 & 0,0 & 100,0 \\
\hline Ogółem & 3,8 & 23,6 & 70,8 & 1,9 & 100,0 \\
\hline \multicolumn{7}{|l|}{ Mężczyźni } \\
\hline $75-79$ & 3,1 & 63,3 & 30,6 & 3,1 & 100,0 \\
\hline $80-84$ & 2,0 & 65,3 & 30,6 & 2,0 & 100,0 \\
\hline $85+$ & 2,9 & 51,4 & 45,7 & 0,0 & 100,0 \\
\hline Ogółem & 2,7 & 61,5 & 33,5 & 2,2 & 100,0 \\
\hline \multicolumn{7}{|l|}{ Ogółem } & 4,6 & 100,0 \\
\hline $75-79$ & 4,1 & 47,4 & 43,9 & 0,6 & 100,0 \\
\hline $80-84$ & 1,9 & 35,8 & 61,7 & 0,0 & 100,0 \\
\hline $85+$ & 4,2 & 25,4 & 70,4 & 2,0 & 100,0 \\
\hline Ogółem & 3,4 & 37,4 & 57,2 & & \\
\hline
\end{tabular}

Źródło: wyniki badań własnych

Wiek w powszechnej opinii jest wyznacznikiem stanu zdrowia. Sprawdźmy zatem, jak respondenci wchodzący w skład różnych grup wiekowych oceniali swoje zdrowie. Pamiętać należy, iż poniższe dane odnoszą się do samooceny stanu zdrowia, a więc do kategorii subiektywnej, tj. podatnej na stany emocjonalne.

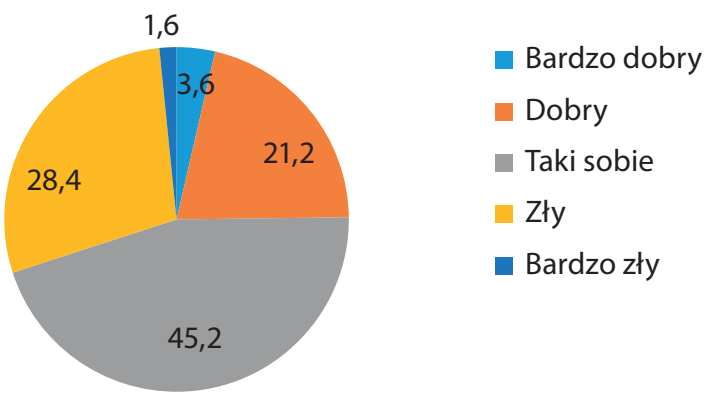

Rysunek 2. Samoocena stanu zdrowia przez seniorów po 75. roku życia $(N=500)$

Żródło: wyniki badań własnych

Większość osób starszych oceniało swój stan zdrowia jako taki sobie (45\%). Respondenci, którzy oceniali swój stan zdrowia negatywnie (źle lub bardzo źle), stanowili 30\% ogółu badanych po 75. roku życia. Odsetek seniorów deklarujących „dobry” i „bardzo dobry” stan zdrowia wynosił niespełna 25\% (rys. 2).

W grupie kobiet mamy do czynienia z przewagą ocen niekorzystnych. Odpowiedzi „zły” i „bardzo zły” udzieliło ponad 38\% starszych kobiet. Mężczyźni oceniają swój 
stan zdrowia zdecydowanie korzystniej, udział powyższych - najmniej optymistycznych - wariantów odpowiedzi kształtuje się na poziomie nieco ponad 15\% (rys. 3).
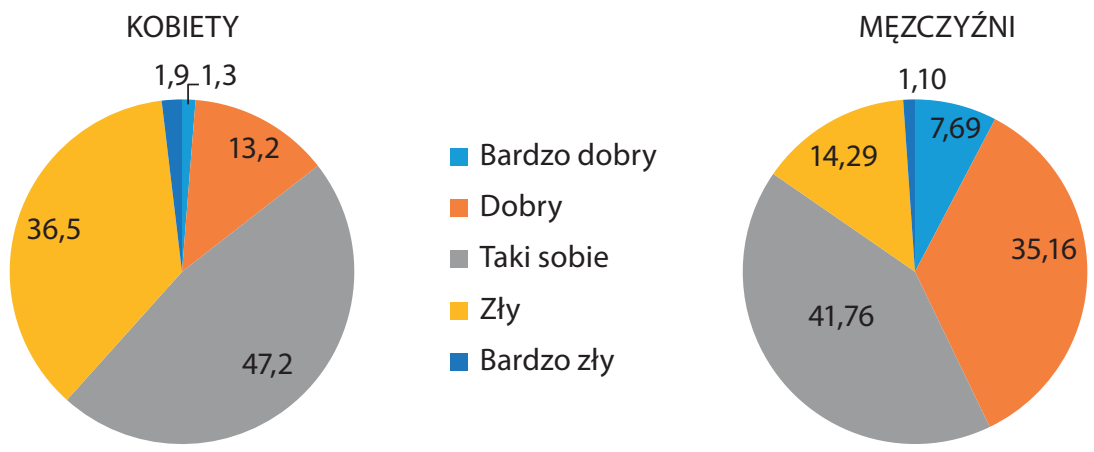

Rysunek 3. Samoocena stanu zdrowia kobiet i mężczyzn po 75. roku życia (w \%)

Źródło: wyniki badań własnych

Tabela 7. Samoocena stanu zdrowia przez respondentów (w \%)

\begin{tabular}{|l|c|c|c|c|}
\hline \multirow{2}{*}{ Samoocena stanu zdrowia } & \multicolumn{4}{|c|}{ Grupa wiekowa } \\
\cline { 2 - 5 } & $\mathbf{7 5 - 7 9}$ & $\mathbf{8 0 - 8 4}$ & $\mathbf{7 5}$ i więcej & $\mathbf{8 5}$ i więcej \\
\hline Bardzo dobry & 6,1 & 3,7 & 3,6 & 0,0 \\
\hline Dobry & 30,6 & 18,5 & 21,2 & 11,3 \\
\hline Taki sobie & 45,4 & 34,0 & 45,2 & 57,7 \\
\hline Zły & 16,8 & 42,0 & 28,4 & 28,9 \\
\hline Bardzo zły & 1,0 & 1,9 & 1,6 & 2,1 \\
\hline Ogółem & 100,0 & 100,0 & 100,0 & 100,0 \\
\hline
\end{tabular}

Źródło: wyniki badań własnych

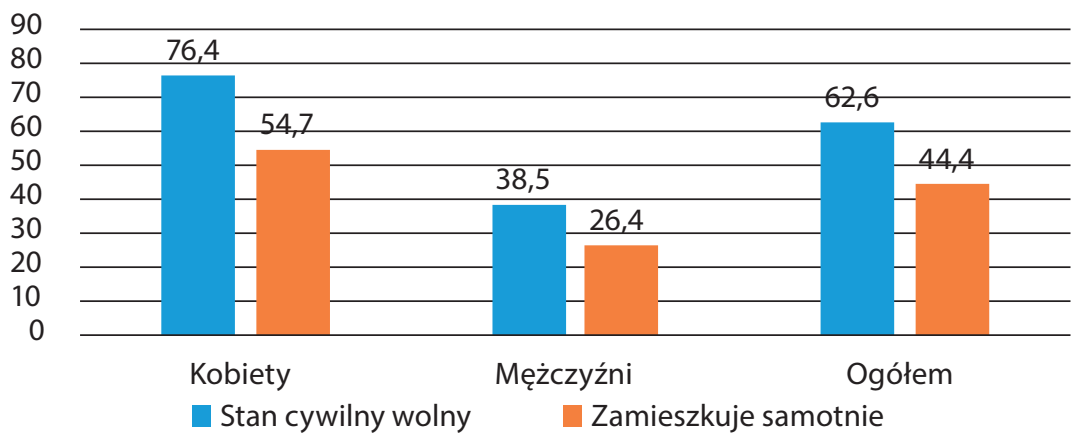

Rysunek 4. Osoby po 75. roku życia, będące stanu wolnego i zamieszkujące samotnie (w \%)

Źródło: wyniki badań własnych 
Generalnie mamy do czynienia ze wzrostem negatywnych ocen stanu zdrowia w starszych grupach wiekowych. Jednocześnie wśród osób po 85. roku życia zmniejsza się częstość wyboru wariantu „zły”, a zwiększa się odpowiedzi „tak sobie”, co świadczy o lepszej samoocenie stanu zdrowia „najstarszych starych” (tab. 7). Wskazywałoby to, iż z jednej strony do bardziej zaawansowanego wieku dożywają jednostki o lepszych predyspozycjach genetycznych i prozdrowotnym stylu życia, z drugiej zaś strony osiąganiu zaawansowanego wieku towarzyszy często przekonanie o relatywnie (w porównaniu do innych osób w zbliżonym wieku) dobrym stanie własnego zdrowia (Szukalski, 2003: 19-32).

Tabela 8. Forma zamieszkiwania badanych seniorów

\begin{tabular}{|c|c|c|c|c|c|c|c|c|c|}
\hline \multirow{3}{*}{$\begin{array}{c}\text { Grupa } \\
\text { wiekowa }\end{array}$} & \multicolumn{9}{|c|}{ Forma zamieszkiwania } \\
\hline & 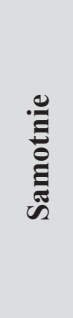 & 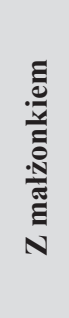 & 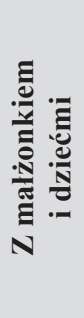 & 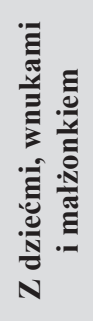 & 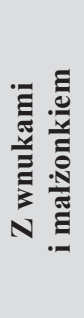 & 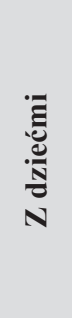 & 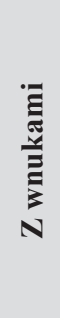 & 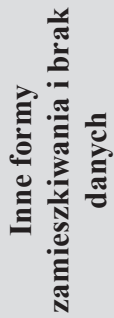 & 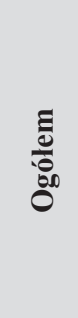 \\
\hline & \multicolumn{9}{|c|}{ w\% } \\
\hline \multicolumn{10}{|c|}{ Kobiety } \\
\hline $75-79$ & 50,0 & 28,6 & 3,1 & 1,0 & 0,0 & 12,2 & 0,0 & 5,1 & 100,0 \\
\hline $80-84$ & 55,8 & 14,2 & 3,5 & 3,5 & 1,8 & 14,2 & 0,0 & 7,1 & 100,0 \\
\hline $85+$ & 57,9 & 9,3 & 7,5 & 0,0 & 0,0 & 17,8 & 4,7 & 2,8 & 100,0 \\
\hline $75+$ & 54,7 & 17,0 & 4,7 & 1,6 & 0,6 & 14,8 & 1,6 & 5,0 & 100,0 \\
\hline \multicolumn{10}{|c|}{ Mężczyźni } \\
\hline $75-79$ & 28,6 & 55,1 & 4,1 & 4,1 & 0,0 & 4,1 & 0,0 & 4,1 & 100,0 \\
\hline $80-84$ & 24,5 & 61,2 & 4,1 & 0,0 & 0,0 & 4,1 & 2,0 & 4,1 & 100,0 \\
\hline $85+$ & 22,9 & 45,7 & 5,7 & 0,0 & 0,0 & 11,4 & 5,7 & 8,6 & 100,0 \\
\hline $75+$ & 26,4 & 54,9 & 4,4 & 2,2 & 0,0 & 5,5 & 1,6 & 4,9 & 100,0 \\
\hline \multicolumn{10}{|c|}{ Ogółem } \\
\hline $75-79$ & 39,3 & 41,8 & 3,6 & 2,6 & 0,0 & 8,2 & 0,0 & 4,6 & 100,0 \\
\hline $80-84$ & 46,3 & 28,4 & 3,7 & 2,5 & 1,2 & 11,1 & 0,6 & 6,2 & 100,0 \\
\hline $85+$ & 49,3 & 18,3 & 7,0 & 0,0 & 0,0 & 16,2 & 4,9 & 4,2 & 100,0 \\
\hline $75+$ & 44,4 & 30,8 & 4,6 & 1,8 & 0,4 & 11,4 & 1,6 & 5,0 & 100,0 \\
\hline
\end{tabular}


Bycie osobą stanu wolnego nie oznacza samotnego zamieszkiwania. Udział seniorów samotnie mieszkających jest znacznie mniejszy od frakcji osób stanu wolnego - brak małżonka nie zawsze skutkuje samotnym zamieszkiwaniem.

Ponad 50\% badanych to osoby, które współzamieszkują z innymi - najczęściej ze współmałżonkiem (30,8\%). Udział seniorów mieszkających samotnie nie przekracza $45 \%$ badanych. Zamieszkiwanie samotnie bądź z innymi osobami jest silnie zróżnicowane w zależności od płci badanych seniorów. Sytuacja mężczyzn jest zdecydowanie korzystniejsza - częściej zamieszkują ze współmałżonką (54,9\%), rzadziej samotnie (26\%). W przypadku badanych kobiet ponad połowa $(54,7 \%)$ zamieszkuje w gospodarstwach jednoosobowych, jedynie 17\% mieszka ze współmałżonkiem, a 14,8\% ze swoimi dziećmi (tab. 8). Wraz z wiekiem zmniejsza się liczba osób zamieszkujących ze współmałżonkiem (zarówno kobiet, jak i mężczyzn), jednocześnie wzrasta udział osób zamieszkujących samotnie i z dziećmi.

\section{Chęć zmiany miejsca zamieszkania w starszym wieku i motywy potencjalnej zmiany}

W niniejszym badaniu cześć pytań dotyczyła określenia skłonności do migracji w przyszłości i potencjalnych motywów przyszłej przeprowadzki.

Prezentowane dane dotyczące charakterystyk demograficznych badanych oraz powodów zmiany miejsca zamieszkania dla każdego z miast osobno były na tyle mało liczne, iż nie można było zastosować zwyczajowo używanych wskaźników struktury. Ponadto nie występowały znaczące różnice między miastami w zaznaczanych przez respondentów (zarówno kobiety, jak i mężczyzn) wariantach odpowiedzi. W związku z tym większość danych dotyczących przemieszczeń będzie prezentowana dla obu płci oraz wszystkich miast łącznie.

Wcześniejsze badania prowadzone w Polsce oraz innych krajach (Latuch, 1977; Synak, 2002; Stolarczyk, 1985; Cuba, Hummon, 1993) świadczą, iż seniorzy to subpopulacja niechętnie zmieniająca miejsce zamieszkania i to bez względu na charakter miejscowości zamieszkania (miasto, wieś) oraz sytuację mieszkaniową czy ekonomiczną.

Wyniki niniejszego badania również potwierdziły niechęć osób starszych do przeprowadzek. $88 \%$ badanych seniorów nie zamierza dobrowolnie zmienić miejsca zamieszkania. W przypadku seniorów, którzy byli skłonni do migracji w przyszłości, przeprowadzka była uwarunkowana główne względami zdrowotnymi (tab. 9), a wśród podawanych przyczyn respondenci wskazywali najczęściej potrzebę opieki ze strony rodziny lub instytucji (50\%), leczenie i rehabilitację $(18,2 \%)$ oraz - z czynników pozazdrowotnych - atrakcyjną okolicę do zamieszkania $(16,8 \%)$. 
Tabela 9. Przyczyny potencjalnej zmiany miejsca zamieszkania $(N=60)$

\begin{tabular}{|l|l|r|}
\hline \multicolumn{2}{|c|}{ Wyszczególnienie } & \% \\
\hline \multirow{4}{*}{$\begin{array}{l}\text { Sprawy } \\
\text { rodzinne }\end{array}$} & Wdowieństwo & 1,8 \\
\cline { 2 - 3 } & Łączenie rodzin & 1,8 \\
\cline { 2 - 3 } & Towarzyszenie rodzinie w przeprowadzce & 1,8 \\
\cline { 2 - 3 } Zdrowie & Inne & 0,0 \\
\cline { 2 - 3 } & Leczenie, rehabilitacja & 18,2 \\
\cline { 2 - 3 } & Lepszy dostęp do służby zdrowia & 5,5 \\
\cline { 2 - 3 } & Potrzeba opieki ze strony rodziny lub instytucji & 50,5 \\
\cline { 2 - 3 } $\begin{array}{l}\text { Warunki } \\
\text { mieszkaniowe }\end{array}$ & Inne & 0,0 \\
\cline { 2 - 3 } & $\begin{array}{l}\text { Złe warunki mieszkaniowe w obecnym miejscu zamieszkania (np. } \\
\text { zbyt małe mieszkanie, brak wody bieżącej) }\end{array}$ & 1,8 \\
\cline { 2 - 3 } & Wysokie opłaty mieszkaniowe & 1,8 \\
\cline { 2 - 3 } & Atrakcyjna okolica na osiedlenie się & 0,0 \\
\cline { 2 - 3 } & Inne & 100,0 \\
\hline
\end{tabular}

Źródło: wyniki badań własnych

Tabela 10. Odpowiedzi na pytanie o przyczynę potencjalnej zmiany miejsca zamieszkania według grup wiekowych (w osobach; $N=60$ )

\begin{tabular}{|l|l|c|c|c|}
\cline { 2 - 4 } \multicolumn{2}{|c|}{} & $\mathbf{7 5 - 7 9}$ & $\mathbf{8 0 - 8 4}$ & $\mathbf{8 5}$ lat i więcej \\
\hline \multirow{5}{*}{ Sprawy rodzinne } & Wdowieństwo & - & 1 & - \\
\cline { 2 - 5 } & Lączenie rodzin & 1 & - & - \\
\cline { 2 - 5 } & $\begin{array}{l}\text { Towarzyszenie rodzinie w przepro- } \\
\text { wadzce }\end{array}$ & - & 2 & 3 \\
\cline { 2 - 5 } & Inne & - & - & - \\
\hline \multirow{5}{*}{ Zdrowie } & Leczenie, rehabilitacja & 5 & 5 & - \\
\cline { 2 - 5 } & Lepszy dostęp do służby zdrowia & 2 & 1 & - \\
\cline { 2 - 5 } & $\begin{array}{l}\text { Potrzeba opieki ze strony rodziny lub } \\
\text { instytucji }\end{array}$ & 7 & 10 & 13 \\
\cline { 2 - 5 } & Inne & - & - & - \\
\hline \multirow{5}{*}{$\begin{array}{l}\text { karunki miesz- } \\
\text { Złe warunki mieszkaniowe w po- } \\
\text { przednim miejscu zamieszkania (np. } \\
\text { zbyt małe mieszkanie, brak wody } \\
\text { bieżącej) }\end{array}$} & 1 & - & - \\
\cline { 2 - 5 } & Wysokie opłaty mieszkaniowe & 1 & - & - \\
\cline { 2 - 5 } & Atrakcyjna okolica na osiedlenie się & 7 & 1 & - \\
\cline { 2 - 5 } & Inne & - & - & - \\
\hline \multirow{2}{*}{ Lączna liczba osób } & 24 & 20 & 16 \\
\hline
\end{tabular}

Źródło: wyniki badań własnych 
W miarę przechodzenia do starszych grup wiekowych malała skłonność do zmiany miejsca zamieszkania, wzrastało znaczenie motywów migracji związanych ze zdrowiem i sprawami rodzinnymi, a malało znaczenie czynników związanych z warunkami mieszkaniowymi (tab. 10). Istotną zależność między wiekiem badanych seniorów a ich skłonnością do zmiany miejsca zamieszkania i powodami migracji potwierdzają obliczone współczynniki zbieżności V-Cramera ${ }^{3}$.

Seniorzy, którzy deklarowali niechęć do migracji w przyszłości, zapytani: "Co musiałoby się stać w Pana/Pani życiu, aby zmienił/zmieniła Pan/Pani miejsce zamieszkania?", wskazywali głównie na pogorszenie się stanu zdrowia (46\%) oraz towarzyszenie członkom rodziny w migracji (38\%). W przypadku osób, które w przyszłości nie zamierzały zmieniać miejsca zamieszkania, nie wystąpiła istotna zależność statystyczna między ich wiekiem a wystąpieniem określonego zdarzenia wpływającego na migrację.

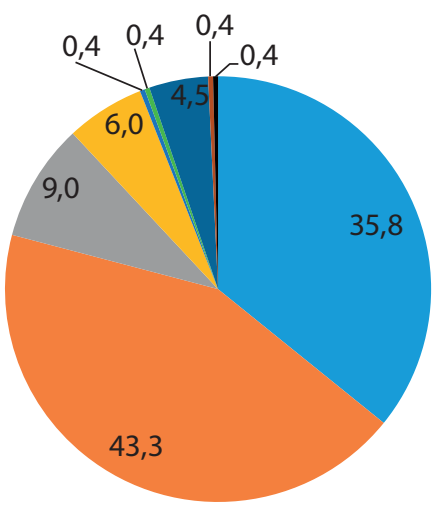

$$
\begin{aligned}
& \text { Zmiana mieszkania przez członków } \\
& \text { rodziny wspierających Pana/Panią } \\
& \text { Pogorszenie się stanu zdrowia } \\
& \text { uniemożliwiające samodzielne } \\
& \text { funkcjonowanie } \\
& \text { Wzrost kosztów utrzymania } \\
& \text { mieszkania } \\
& \text { Inne, jakie: } \\
& \text { Kupno domu przez córkę } \\
& \text { Tylko ważny powód } \\
& \text { Nie ma takiej możliwości } \\
& \text { Np. zmiana na parter z ogródkiem } \\
& \text { Brak danych }
\end{aligned}
$$

Rysunek 5. Co musiałoby się stać w Pana/Pani życiu, aby zmienił/zmieniła Pan/Pani miejsce zamieszkania? $(N=440)$

\section{Źródło: wyniki badań własnych}

Zmiana miejsca zamieszkania w przyszłości jest ściśle związana ze stanem zdrowia. Osoby deklarujące bardzo dobry i dobry stan zdrowia relatywnie rzadziej zgłaszały chęć zmiany miejsca zamieszkania, a wśród potencjalnych przyczyn przeprowadzki nie pojawiały się motywy zdrowotne. Seniorzy oceniający swój stan zdrowia jako „taki sobie” i „gorszy” częściej wyrażali chęć przeprowadzki w przyszłości, a jako powód migracji wskazywali głównie motywy zdrowotne.

\footnotetext{
${ }^{3} V=0,632$ przy poziomie istotności $p=0,001$ oraz $V=0,722$ dla $p=0,05$.
} 
Potencjalne motywy migracji można więc podzielić na dwie kategorie:

1) takie, które wymuszają migracje (wdowieństwo, towarzyszenie rodzinie, zły stan zdrowia wymagający leczenia i długoterminowej opieki, warunki mieszkaniowe i koszty utrzymania mieszkania) oraz

2) takie, które mają charakter dobrowolny (łączenie rodziny, atrakcyjniejsza okolica do zamieszkania).

\section{Wnioski}

Głównym celem niniejszego artykułu było rozpoznanie potencjalnych motywów przyszłych przemieszczeń. Uzyskane wyniki potwierdzają prowadzone na początku lat siedemdziesiątych i w latach osiemdziesiątych XX wieku badania dotyczące przyczyn migracji osób starszych (Latuch, 1977: 51-69; Stolarczyk, 1985: 1-210), które wskazywały, iż starsi ludzie niechętnie opuszczają swoje miejsce zamieszkania. Ciągle jeszcze w społeczeństwie mamy do czynienia z silnym przekonaniem, że „starych drzew” się nie przesadza, co pokazało badanie PolSenior. Osoby starsze niechętnie zmieniają miejsce zamieszkania, a jeśli dochodzi do migracji, to najczęściej ma ona charakter wymuszony złym stanem zdrowia. Potwierdzają to również wyniki ostatniego spisu ludności z 2011 roku, które wskazują, że wśród osób po 75. roku życia motyw przeprowadzki związany z leczeniem, rehabilitacją czy opieką ze strony rodziny pojawiał się znacznie częściej niż wśród ogółu osób zmieniających miejsce zamieszkania w latach 2002-2011.

Przewaga odpływu najstarszych seniorów nad ich napływem do wielkich miast jest w dużej mierze efektem suburbanizacji. Najstarsi seniorzy, którym stan zdrowia nie pozwala na samodzielną egzystencję, przeprowadzają się do najbliższych opiekunów, często wbrew własnej woli.

Pamiętać należy jednak o specyfice badanej grupy seniorów mieszkańców wielkich miast, którzy - jak wskazuje badanie PolSenior - charakteryzują się na ogół wyższym poziomem wykształcenia, co przekłada się na ich lepszą sytuację materialną w porównaniu z ich rówieśnikami z mniejszych miast i wsi.

Obecnie wzrost przeciętnej długości życia, w polepszającej się kondycji fizycznej, prowadzi do odroczenia decyzji o przeprowadzce na późniejszy etap. W przyszłości wydłużenie się życia prowadzić będzie do konieczności zapewnienia przez rodziny opieki nad najstarszymi krewnymi (rodzicami, dziadkami). Jednocześnie ograniczenie liczby posiadanego potomstwa będzie skutkować ograniczeniem potencjalnych opiekunów oraz zwiększeniem ich obciążenia i wzrostem zapotrzebowania na opiekę ze strony systemu pomocy społecznej. W nieodległej przyszłości może to skutkować wzrostem liczby migracji związanych z opieką instytucjonalną (Kałuża-Kopias, 2014b: 32-42; Kałuża-Kopias, 2015: 98-118). 


\section{Bibliografia}

Bean F.D, Myers G.C., Angel J.L., Galle O.R. (1994), Geographic concentration, migration, and population redistribution among the elderly, [w:] L.G. Marin, S.H. Preston, Demography of aging, NAP, Washington.

Bień B. (2002), Stan zdrowia i sprawność ludzi starszych, [w:] B. Synak (red.), Polska starość, Wydawnictwo Uniwersytetu Gdańskiego, Gdańsk.

Błędowski P., Wilmowska-Pietruszyńska A., (2009), Organizacja opieki długoterminowej w Polsce. Problemy i propozycje rozwiazań. Organising long-term care in Poland. Main problems and possible solutions, „Polityka Społeczna”, nr 7, s. 9-13.

Bojanowska E. (2008), Opieka nad ludźmi starszymi, [w:] P. Szukalski, I. Oliwińska, E. Bojanowska, Z. Szweda-Lewandowska (red.), To idzie starość - polityka społeczna a przygotowanie do starzenia się ludności Polski, ISP, Warszawa.

Breuer T. (2005), Retirement Migration or Second-home Tourism? German Senior Citizens on the Canary Islands, „Die Erde”, no. 136(3), s. 313-333.

Colsher P.L., Wallach R.B. (1990), Health and other social antecedents of relocation in rural elderly person, „J. Gerontol”, vol. 45(1), s. 100-136.

Cuba L.J., Hummon D.M. (1993), A place to call home, Identification with dwelling community and religion, „Sociol Q”, vol. 34, s. 111-131.

GUS (2014), Migracje wewnętrzne ludności. Narodowy Spis Powszechny Ludności i Mieszkań 2011, Warszawa.

Haas W.H., Serow W.J. (1993), Amenity retirement migration process: A model and preliminary evidence, ,The Gerontologist”, vol. 33, s. 212-220.

He W., Schachter J. (2003), Internal migration of the older population, 1995 to 2000, US Department of Commerce, Economics and Statistics Administration, US Census Bureau.

Kałuża D. (2008), Migracje seniorów, [w:] T. Kowaleski, P. Szukalski (red.), Starzenie się ludności Polski. Między demografia a gerontologia społeczna, Wydawnictwo Uniwersytetu Łódzkiego, Łódź.

Kałuża-Kopias D. (2011), Migracje seniorów w największych miastach w Polsce, [w:] T.J. Kowaleski (red.), Przestrzenne zróżnicowanie starzenia się ludności Polski, przyczyny, etapy, nastepstwa, Wydawnictwo Uniwersytetu Łódzkiego, Łódź.

Kałuża-Kopias D. (2014a), Specyfika przemieszczeń wewnętrznych osób starszych w Polsce, „Studia Demograficzne", nr 2(166), s. 97-120.

Kałuża-Kopias D. (2014b), Demograficzne skutki międzynarodowych migracji w wybranych krajach Unii Europejskiej ze szczególnym uwzględnieniem Polski, [w:] A. Rączaszek, W. Koczur (red.), Polityka społeczna wobec przemian demograficznych, „Studia Ekonomiczne. Zeszyty Naukowe Wydziałowe Uniwersytetu Ekonomicznego w Katowicach", nr 167, s. 32-42.

Kałuża-Kopias D. (2015), Polscy emigranci w późnym wieku, „Acta Universitatis Lodziensis. Folia Oeconomica", nr 4(315), http://dx.doi.org/10.18778/0208-6018.315.05.

Krzyżanowski Ł. (2012), Zobowiąania rodzinne i dynamika wykluczenia w transnarodowej przestrzeni społecznej. Polacy w Islandii i ich starzy rodzice w Polsce, „Studia Migracyjne - Przegląd Polonijny", nr 38(1/143), s. 125-142.

Kurek, S. (2008), Typologia starzenia się ludności w ujęciu przestrzennym, Wydawnictwo Naukowe Akademii Pedagogicznej, Kraków.

La Parra D., Mateo M.A. (2008), Health status and access to health care of British nationals living on the Costa Blanca, Spain, „Ageing and Society”, vol. 28(1), s. 85-102.

Latuch M. (1977), Przyczyny emigracji osób w starszym wieku z największych miast w Polsce, „Studia Demograficzne”, nr 50, s. 51-69.

Longino Ch.F. (1987), Migration patterns among the elderly: A developmental perspective, „The Gerontologist”, vol. 27, s. 266-272. 
Longino Ch.F., Bradley D.E. (2001), Geographical distribution and migration, [w:] R.H. Binstock, L.K. Georg (eds.), Aging and the Social Sciences, Oxford University Press, Oxford.

Longino C.F. Jr., Warnes A.M. (2005), Migration and older people, [w:] M.L. Johnson (ed.), Cambridge Encyclopaedia of Ageing, Cambridge University Press, Cambridge.

Mossakowska M., Więcek A., Błędowski P. (2012), PolSenior. Aspekty medyczne, psychologiczne, socjologiczne i ekonomiczne starzenia się ludności w Polsce, Termedia Wydawnictwo Medyczne, Poznań.

Ptak E. (2012), Migracje międzynarodowe seniorów, „Polityka Społeczna”, nr 10, s. 21-26.

Quandango J. (2002), Aging and the life course, Pepper Institute on Aging and Public Policy, Florida State University, Florida.

Rogers A. (1990), Return migration to region of birth among retirement-age persons in the United States, „Journal of Gerontology: Social Sciences”, vol. 5, s. 128-134.

Schiamberg L.B., McKinney K.G. (2003), Factors Influencing Expectations to Move or Age in Place at Retirement Among 40- to 65-Year-Olds, ,Journal of Applied Gerontology”, vol. 22, s. 19-41.

Stolarczyk K. (1985), Społeczno-ekonomiczne czynniki warunkujące migracje osób w starszym wieku w Polsce, „Monografie i Opracowania”, SGPiS, Instytut Statystyki i Demografii, Warszawa.

Stolarczyk K. (1986), Społeczno-demograficzne aspekty migracji osób w starszym wieku, [w:] J. Witkowski (red.), Społeczno-demograficzne i ekonomiczne aspekty wspótczesnych migracji $w$ Polsce, ,Monografie i Opracowania”, SGPiS, Instytut Statystyki i Demografii, Warszawa.

Suzman R.M., Manton K.G., Willis D.P. (1992), Introducing the oldest old, [w:] R.M. Suzman, D.P. Willis, K.G. Manton (eds.), The oldest old, Oxford University Press, Oxford-New York.

Synak B. (red.) (2000), Ludzie starzy w warunkach transformacji ustrojowej, Wydawnictwo Uniwersytetu Gdańskiego, Gdańsk.

Synak B. (red.) (2002), Polska starość, Wydawnictwo Uniwersytetu Gdańskiego, Gdańsk.

Szukalski P. (2003), Raport merytoryczny z realizacji projektu badawczego. Status rodzinny a sytuacja zdrowotna i bytowa osób sędziwych w środowisku wielkomiejskim, grant 2H2OE03424, http://dspace.uni.lodz.pl/xmlui/bitstream/handle/11089/3625/Ca\%C5\%820\%C5\%9B\%C4\%87. pdf?sequence=1\&isAllowed=y [dostęp: 20.08.2016].

Szukalski P. (2010), Starzenie się ludności Łodzi na tle największych Polskich miast od początku $X X$ wieku, „Acta Universitatis Lodziensis. Folia Sociologica”, nr 35, s. 103-125.

Uren Z., Goldring S. (2007), Migration trends at older ages in England and Wales, „Population Trends", no. 130, s. 31-41, www.statistics.gov.uk [dostęp: 10.12.2012].

Walters W.H. (2006), Later-Life Migration in the United States, A Review of Recent Research, http:// www.pineforge.com/ballantinestudy/articles/Chapter14_Article04.pdf [dostęp: 10.02.2016].

Wiseman R.F. (1980), Why older people move theoretical issues, „Research on Aging”, vol. 2(2), s. $141-154$.

\section{The tendency to migration of eldery people inhabitants of big cities}

Abstract: Poland's population is aging like the populations in most developed countries. The fast rising number of the oldest old (the so-called "double aging") and their problems will probably be the dominant theme in the debate about seniors in coming decades. The purpose of this paper is to present the potential motives of migration of people over the age of 75 residents of large cities in Poland. 
Performed material from their own research that has been carried between February and August 2016. The analysis results indicate that older people are reluctant to change their place of residence, and the main theme of migration are health problems.

Keywords: gerontology; demography; migration seniors; determinants of migration

JEL: J1

\begin{tabular}{|l|l|}
\hline \multirow{2}{*}{ OPEN ACCESS } & $\begin{array}{l}\text { C by the author, licensee Łódź University - Łódź University Press, Łódź, Poland. } \\
\text { This article is an open access article distributed under the terms and conditions } \\
\text { of the Creative Commons Attribution license CC-BY } \\
\text { (http://creativecommons.org/licenses/by/3.0/) }\end{array}$ \\
\cline { 2 - 2 } \\
Received: 2016-09-10; verified: 2017-03-24. Accepted: 2017-07-31
\end{tabular}

